ББК 63.4

$$
\begin{gathered}
\text { Организация конференции и издание материалов проведены } \\
\text { при финансовой поддержке Российского фонда фундаментальных исследований, } \\
\text { проект № 19-09-20008 }
\end{gathered}
$$

Утверждено к печати Ученым советом ИИМК РАН

Редакционная коллегия тома II: А. В. Поляков, Е. С. Ткач (отв. редакторы), М. Т. Кашуба, Л. Б. Кирчо, Е. А. Черлёнок, В. Я. Стёганцева, А. И. Климушина

Рещензенты: д. и. н. Л. Б. Вишняцкий, д. и. н. А. А. Выборнов

Программный комитет конференции: академик РАН, д. и. н., проф. М. Б. Пиотровский (Государственный Эрмитаж, почетный председатель); д. и. н. В. А. Лапшин (ИИМК РАН, председатель); д. и. н. А. В. Головнёв (МАЭ РАН, сопредседатель); д. и. н. В. А. Дергачёв (Высшая антропологическая школа, Молдова, сопредседатель); д. и. н. И. Ф. Попова (ИВР РАН, сопредседатель); академик АН Республики Узбекистан, д. и. н., проф. Э. В. Ртвеладзе (сопредседатель); к. и. н. А. В. Поляков (ИИМК РАН, зам. председателя); к. и. н. В. А. Алёкшин (ИИМК РАН, зам. председателя); д. и. н. Ю. Е. Берёзкин (МАЭ РАН); Dr., Prof. Н. Бороффка

(Германский археологический институт, Германия); В. С. Бочкарёв (ИИМК РАН);

Dr. Э. Кайзер (Свободный университет Берлина, Германия); к. и. н. М. Т. Кашуба (ИИМК РАН); д. и. н. Л. Б. Кирчо (ИИМК РАН); к. и. н. А. В. Кияшко (Южный федеральный университет); к. и. н. П. Ф. Кузнецов (СГСПУ); к. и. н. Н. М. Малов (СНИГУ); к. и. н. В. П. Никоноров (ИИМК РАН); Ю. Ю. Пиотровский (Государственный Эрмитаж); д. и. н., проф. Д. Г. Савинов (Институт истории СПбГУ); к. и. н. В. Н. Седых (Институт истории СПбГУ); к. и. н. Н. Н. Скакун (ИИМК РАН); к. и. н. Н. Ф. Соловьёва (ИИМК РАН); к. и. н. А. И. Торгоев (Государственный Эрмитаж); к. и. н. Е. А. Черлёнок (Институт истории СПбГУ)

Организационный комитет конференции: к. и. н. А. В. Поляков (ИИМК РАН, председатель); к. и. н. В. А. Алёкшин (ИИМК РАН, зам. председателя); В. С. Бочкарёв (ИИМК РАН); к. и. н. М. Т. Кашуба (ИИМК РАН); д. и. н. Л. Б. Кирчо (ИИМК РАН);

А. И. Климушина (ИИМК РАН, отв. секретарь); к. и. н. В. П. Никоноров (ИИМК РАН); Ю. Ю. Пиотровский (Государственный Эрмитаж); В. Я. Стеганцева (ИИМК РАН); В. В. Терёхина (ИИМК РАН, МАЭ РАН, отв. секретарь); к. и. н. Е. С. Ткач (ИИМК РАН); И. Ж. Тутаева (Государственный Эрмитаж); к. и. н. Е. А. Черлёнок (Институт истории СПбГУ)

Древности Восточной Европы, Центральной Азии и Южной Сибири в контексте связей и взаимодействий в евразийском культурном пространстве (новые данные и концепции): Материалы Международной конференции, 18-22 ноября 2019 г., Санкт-Петербург. Т. ІІ. Связи, контакты и взаимодействия древних культур Северной Евразии и цивилизаций Востока в эпоху палеометалла (IV-I тыс. до н. э.). К 80-летию со дня рождения выдающегося археолога В. С. Бочкарёва. - СПб.: ИИМК РАН, Невская Типография, 2019. - 287 с.

ISBN 978-5-907053-35-9

DOI 10.31600/978-5-907053-35-9 


\title{
THE ORIGIN AND DEVELOPMENT OF THE TEXTILE CULTURE IN THE LATE BRONZE AGE OF THE SOUTHERN URALS
}

Polina S. Medvedeva

South Ural State Humanitarian Pedagogical University, Chelyabinsk, Russia

Keywords: textile, Bronze Age, Southern Urals, imprints of textile.

The textile culture in the Late Bronze Age of the Southern Urals (Sintashta, Petrovka and Alakul cultures) is characterized by the employment of woolen fibers for manufacturing of woven and twisted textiles, dyeing with plant pigments, the use of the textiles for fabrication of costumes and in ceramic manufacture. Sintashta technologies demonstrate a rupture with the previous Eneolithic period. They have the closest parallels at Catacomb sites and were inherited by the Petrovka and Alakul people. During the first half of the $2^{\text {nd }}$ mill. $B C$, gradual change took place in the predominance of the types of textiles from the balanced ones in the Sintashta period to the thin unbalanced in the Alakul phase. The textile culture of the Southern Urals in the Late Bronze Age was a constituent of a single technological massif of the steppe and forest-steppe zone of the Srubnaya-Andronovo "world", as well as, possibly, also of the "Andronovoid" forest societies linked with the latter.

\section{МЕТАЛЛИЧЕСКИЕ ОРУДИЯ И ИЗДЕЛИЯ ФИНАЛА БРОНЗОВОГО ВЕКА ЮЖНОГО ЗАУРАЛЬЯ}

\author{
И. П. Алаева \\ Южно-Уральский государственный гуманитарно-педагогический университет, Челя- \\ бинск, Россия
}

DOI: $10.31600 / 978-5-907053-35-9-270-272$

Ключевые слова: финал бронзового века, черкаскульская культура, межовская культура, металлургический очаг.

В конце позднего бронзового века в Южном Зауралье происходит смена блока культур синташтинско-алакульского круга на свиту культурных образований андроноидного постандроновского блока. В лесостепной (на границе лесной) зоне появляется мощный блок андроноидных культур. В степной зоне формируется блок культур валиковой керамики. Территория Южного Зауралья становится пограничной зоной, расположенной на стыке этих образований.

Особое место на этой территории занимает черкаскульская культура, представленная в зонах и лесостепи, и степи. Существенную проблему составляет фактическое отсутствие набора культурноопределимых изделий. Набор предметов, характеризующих черкаскульско-межовские комплексы, составлялся из обширного перечня случайных находок (Обыденнов, Шорин 1995) и предметов, происходящих из многослойных поселений степной зоны (Матвеев 2007).

На лесостепном поселении Чебаркуль III обнаружен комплекс предметов финала бронзового века, отложившийся в слое с черкаскульской, межовской керамикой.

Медные однолезвийные ножи с рукоятью (рис. $1,1,4$ ). В типологии Н. А. Аванесовой однолезвийный нож с поселения Чебаркуль III наибольшую близость находит с категорией однолезвийных ножей типа Б - «черенковые» с намечающимся уступом, с ножом из Черноозерье 1, мог. 43 и мог. 126 (Аванесова 1991: рис. 33, 2).

Медные серпы-косари (рис. 1, 2, 3) относятся к категории серпов сосново-мазинского типа. Н. А. Аванесова относит подобные изделия к типу Г - секачи-косари, массивные серповидные изделия, имеющие широкую зону распространения. В. С. Бочкарёв и В. А. Дергачёв дают более подробную типологию серпов этого времени (Бочкарёв, Дергачёв 2002). Для обсуждаемого региона имеют распространение два типа Уральской группы: 


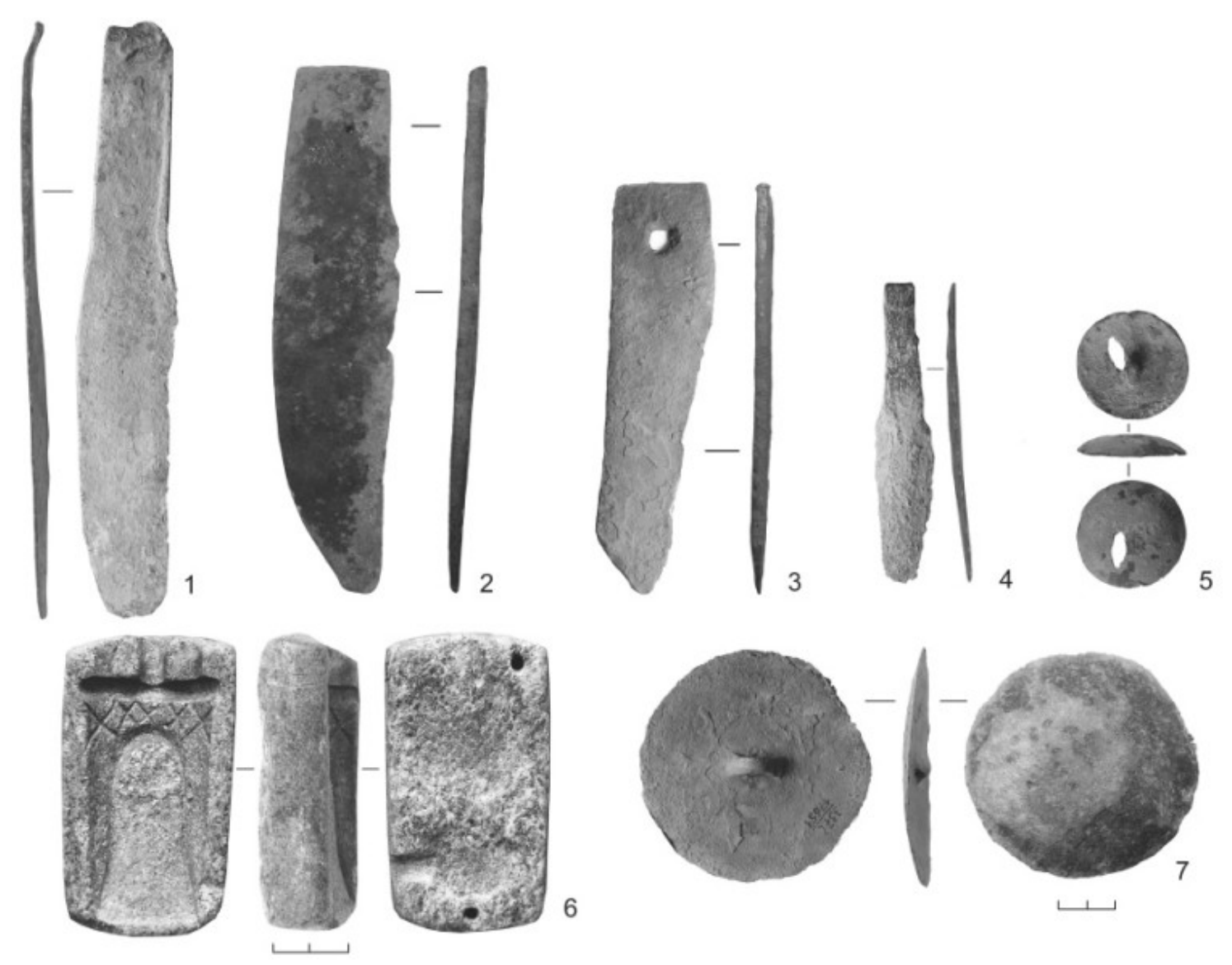

Рис. 1. Металлические изделия финала бронзового века, поселение Чебаркуль III: 1, 4 - медные ножи, 2-3 - медные серпы-косари, 5 - бронзовая бляшка с петелькой, 6 - створка каменной литейной формы кельта, 7 - бронзовый диск-бляшка

тип Сосновая-Маза и тип Явленка (Там же: 47, 107). Интересно, что выявленные на поселении Чебаркуль III серпы-косари имеют достаточно узкое лезвие, отсутствие выраженного изгиба спинки (отчего эти изделия становятся более всего похожими на ножи) и находят наиболее близкие аналогии почти исключительно в памятниках Урало-Тобольского региона как среди изделий типа Сосновая Маза (с отверстием в рукояточной части), так и среди изделий типа Явленка (с крюком на пятке).

Бронзовые бляшки с петелькой, одна из которых имеет достаточно крупные размеры (рис. 1, 5, 6) наиболее близкие аналогии имеют в памятниках Башкирского Приуралья, связанных с черкаскульско-межовским культурным комплексом.

Кроме того, на поселении была обнаружена створка каменной литейной формы безушкового кельта с арочной фаской, пещеркой и валиком, с орнаментом по верхнему краю втулки (рис. 1, 6). Б. Г. Тихонов специально указывал, что подгруппа А группы 2 - кельтытесла с «пещеркой» - известна только в Зауралье. Примечательно, что большинство самих изделий были обнаружены в качестве случайных находок в достаточно обширной зоне. В то время как находки створок литейных форм были приурочены к поселениям Южного Зауралья - Кизильское, Куйсак I.

Таким образом, материалы поселения Чебаркуль III демонстрируют оригинальность предметного комплекса, отличного от степного саргаринско-алексеевского и связанного с черкаскульско-межовским кругом, с блоком андроноидных культур. 


\section{Литература}

Аванесова Н. А. 1991. Культура пастушеских племен эпохи бронзы Азиатской части СССР (по металлическим изделиям). Ташкент.

Дергачёв В. А., Бочкарёв В. С. 2002. Металлические серпы поздней бронзы Восточной Европы. Кишинёв.

Матвеев А. В. 2007. Черкаскульская культура Зауралья // AB ORIGINE: Проблемы генезиса культур Сибири. Тюмень. С. 4-42.

Обыденнов М. Ф., Шорин А. Ф. 1995. Археологические культуры позднего бронзового века древних уральцев (черкаскульская и межовская культуры). Екатеринбург.

\section{METAL TOOLS AND ARTIFACTS OF THE FINAL BRONZE AGE OF THE SOUTHERN TRANS-URAL REGION}

Irina P. Alayeva

South Ural State Humanitarian-Pedagogical University, Chelyabinsk, Russia

Keywords: Final Bronze Age, Cherkaskul culture, Mezhovka culture, metallurgic center.

In the end of the Final Bronze Age, in the Sintashta-Alakul culture in the Southern Trans-Urals, changes occur in the Andronovoid and Post-Andronovoid cultural formations. In the forest-steppe zone and at the border of forest zone the powerful unity of Andronovoid culture tribes appears. In the steppe zone there is a union of the Relief-band (Valikovaya) Pottery people.

The territory of the Southern Trans-Urals becomes a transitional zone located at the junction of these formations. A special place in this territory is held by the Cherkaskul culture distributed both in the forest-steppe and in steppe zones.

The absence of the cultural features of Cherkaskul-Mezhovka complex of tools is among the main difficulties in the present-day studies. This complex is constituted by numerous chance finds and artifacts unearthed at multi-layer settlements in the steppe zone.

In the forest-steppe settlement of Chebarkul III, a complex of artifacts was found in settlement cultural layers with Cherkaskul and Mezhovka pottery. The peculiarities of the objects and their differences from finds from the steppe metallurgic center (culture of the Valikovaya Pottery) suggest the existence of an independent metallurgic center of the Cherkaskul-Mezhovka cultural complex. 